\title{
KEWIRAUSAHAAN PETANI DALAM PENGELOLAAN BISNIS MIKRO DI PEDESAAN
}

\author{
Dumasari \\ Staf Pengajar pada Fakultas Pertanian, Universitas Muhammadiyah Purwokerto \\ Email:dumasarilumongga@yahoo.com
}

\begin{abstract}
This article aims to examine some of the determinants of entrepreneurial farmers and functions in the management of rural micro businesses. Some determinant factors of entrepreneurial farmers can be internal and external. Determinant factors also have the effect of enabling and inhibiting. Entrepreneurship of farmers have some strategic functions in development that encourage micro businesses in rural areas.
\end{abstract}

Keywords : entrepreneurship, farmers, micro businesses and rural

\section{PENDAHULUAN}

Berbagai bentuk upaya peningkatan pendapatan rumahtangga petani di wilayah pedesaan merupakan salah satu tujuan pokok dalam dinamika pembangunan nasional yang berkelanjutan. Hal menjadi suatu yang penting diperhatikan karena mengingat tekanan ancaman kemiskinan pada masyarakat petani di pedesaan masih relatif tinggi.

Persoalan kemiskinan pada petani bukan hanya dikarenakan tekanan dominan dari faktor ekonomi sehubungan dengan keterbatasan modal produksi. Akan tetapi, faktor lain yang justru lebih berpengaruh ialah kualitas sumberdaya manusia petani yang rendah. Hal tersebut dibuktikan dari hasil penelitian Dumasari, et all., (2007) didukung Dumasari dan Watemin (2010) yang menunjukkan bahwa selain tingkat pendidikan formal petani yang relatif rendah (rata-rata sekolah dasar) ternyata tingkat partisipasi dalam berbagai kegiatan pendidikan tak formal juga minim. Jarang sekali petani terutama yang termasuk kategori miskin (buruh tani) turut aktif dalam ragam kegiatan penyuluhan, pelatihan dan demonstrasi cara mengenai sederet informasi, ide-ide dan inovasi teknologi pertanian. Tingkat produktivitas, kreativitas kerja, posisi tawar dan kemampuan kewirausahaan yang dimiliki petani dalam mengelola bisnis kreatif juga tergolong rendah.

Semangat dan kemampuan petani yang relatif lemah dalam kewirausahaan menjadi salah satu faktor sosial ekonomi yang menghambat pengembangan potensi diri dalam mengelola bisnis mikro produktif di pedesaan. Pengelolaan usahatani lamban hingga sulit memperoleh pendapatan yang layak. Kondisi tersebut dapat ditemukan pada petani pembudidaya tanaman pangan dan sayuran di Desa Sikapat yang cenderung mempunyai semangat dan kemampuan kewirausahaan lemah (Dumasari dan Sulistyani, 2002).

Pengambilan keputusan dalam proses adopsi ragam teknologi untuk kepentingan efisiensi bisnis mikro juga ditentukan oleh kemampuan petani dalam penerapan prinsip kewirausahaan. Hasil penelitian Bayu dan Ery (2012) pada Kelompok Petani P3A Mitra Cai di Kecamatan Jatitujuah, Kabupaten Majalengka, Jawa Barat ternyata 
menunjukkan bahwa sikap kewirausahaan dan kompetensi petani merupakan salah satu faktor terpenting yang menentukan penerapan teknologi padi organik. Petani yang belum dan kurang mempunyai jiwa kewirausahaan senantiasa kesulitan mengelola dan mengembangkan diversifikasi usaha secara produktif ditengah potensi sumberdaya lokal yang melimpah di sekeliling lingkungan mukimnya. Untuk itu, tak dapat dielakkan sesungguhnya kewirausahaan memang mempunyai fungsi penting sebagai motor penggerak petani dalam mengembangkan ragam jenis usaha bisnis pertanian secara produktif dan kreatif.

Kewirausahaan termasuk salah satu kebutuhan strategis bagi petani dalam mengelola usaha bisnis mikro berbasis sumberdaya lokal di pedesaan. Intervensi efek globalisasi yang memasuki ranah kawasan kehidupan masyarakat petani di pedesaan menuntut optimalisasi fungsi kewirausahaan yang diharapkan mampu mengarahkan perilaku berorientasi pada better farming, better business dan better living. Berdasarkan hasil penelitian Dumasari, et all., (2013) diketahui bahwa kewirausahaan mampu mendorong produktivitas dan kreativitas kerja petani pengrajin souvenir kreatif olahan limbah kelapa di beberapa wilayah pedesaan Baturaden dan Purbalingga Wetan. Tidak jauh berbeda, hasil penelitian lain yang dilakukan oleh Pujiati dan Dumasari (2012) di pedesaan Kabupaten Banyumas menunjukkan kekuatan pengaruh dari kewirausahaan potensial mendorong petani pengrajin bisnis kreatif pangan olahan singkong mampu memanfaatkan peluang pasar hingga aneka jenis produk yang dihasilkan selalu disesuaikan dengan trend, variasi, cita rasa dan ekspektasi selera konsumen. Oleh karena itu, produktivitas, kreativitas, orientasi bisnis dan posisi tawar tidak dapat terlepaskan dari semangat dan kemampuan kewirausahaan seorang petani karena mengingat posisi strategisnya sebagai pengelola usahatani.

Mengingat pentingnya permasalahan kewirausahaan yang diuraikan di atas memotivasi penetapan tujuan pembahasan artikel ini untuk mengkaji berbagai faktor penentu kewirausahaan petani dan fungsinya bagi proses pengembangan ragam jenis bisnis mikro di pedesaan

\section{RAGAM FAKTOR KEWIRAUSAHAAN PETANI}

\section{PENENTU}

Kewirausahaan merupakan bagian dari realisasi perilaku produktif, kreatif dan inovatif yang dimiliki seseorang termasuk petani. Dengan kewirausahaan, seseorang atau sekelompok orang termasuk petani dapat melakukan proses penciptaan keadaan yang baru secara kreatif dan produktif dimana hasil berbeda dengan yang lama sehingga potensial meningkatkan nilai tambah. Ropke (2004) mengemukakan tiga fungsi kewirausahaan yakni: pertama fungsi rutin untuk pemanfaatan sumberdaya yang dimiliki dengan penerapan prinsip manajemen, kedua fungsi arbitrase untuk pemanfaatan peluang dengan berani mengambil risiko dan ketiga fungsi inovatif untuk pengadaan beragam inovasi bagi pengembangan usaha yang dikelola. Dengan demikian, makna kewirausahaan merupakan refleksi nyata dari sikap, kognitif dan psikomotorik seseorang dalam memanfaatkan berbagai peluang sekaligus kesempatan untuk memperoleh sesuatu yang berguna secara ekonomis bagi diri beserta lingkungannya. Pengembangan kewirausahaan dibutuhkan bagi ragam upaya pemberdayaan petani. Pernyataan tersebut sesuai hasil penelitian Ratnawati (2009) dan Dumasari, et all., (2007). Kedua hasil penelitian tersebut saling menguatkan fakta sosial bahwa upaya pemberdayaan perempuan termasuk wanita tani miskin di pedesaan dapat dilakukan melalui diversifikasi usaha produktif kreatif. Kelancaran proses diversifikasi usaha ini dapat tercapai melalui pengembangan perilaku kewirausahaan dengan penggunaan pendekatan kelompok.

Pada prinsipnya setiap petani memiliki potensi diri untuk mengembangkan semangat dan kemampuan kewirausahaan. Hanya saja hal ini perlu didukung pihak internal 
(kesadaran, kemauan dan kompetensi pribadi) bersama pihak internal (keluarga, lingkungan sosial, investor, pemerintah, tokoh masyarakat, mitra kerja bisnis, konsumen, pedagang dan lainnya). Dukungan yang kuat dari pihak internal dan eksternal berfungsi mendorong keberanian petani mengembangkan kewirausahaan saat mengelola berbagai jenis bisnis mikro di bidang pertanian dan non pertanian. Berbagai faktor yang terkait dengan eksistensi peran keberadaan pihak internal dan eksternal turut menentukan kekuatan sekaligus orientasi kewirausahaan petani.

Ragam faktor penentu tersebut mempunyai kemampuan pengaruh yang kontradiktif karena di satu sisi bisa berfungsi sebagai pendukung; sementara di sisi lain justru menjadi penghambat bagi pengembangan kewirausahaan petani di pedesaan. Meredith (2005) menjelaskan bahwa beberapa faktor penentu yang berharga dalam mempertahankan jiwa sekaligus kemampuan kewirausahaan adalah sikap positif, tekad, pengalaman, ketekunan dan kerja keras. Beberapa faktor yang dikemukakan Meredith tersebut cenderung bersifat internal. Fungsinya ialah menjadi prasyarat bagi seseorang yang mengembangkan kewirausahaan. Adapun faktor internal penentu lain tercantum pada Gambar 1.

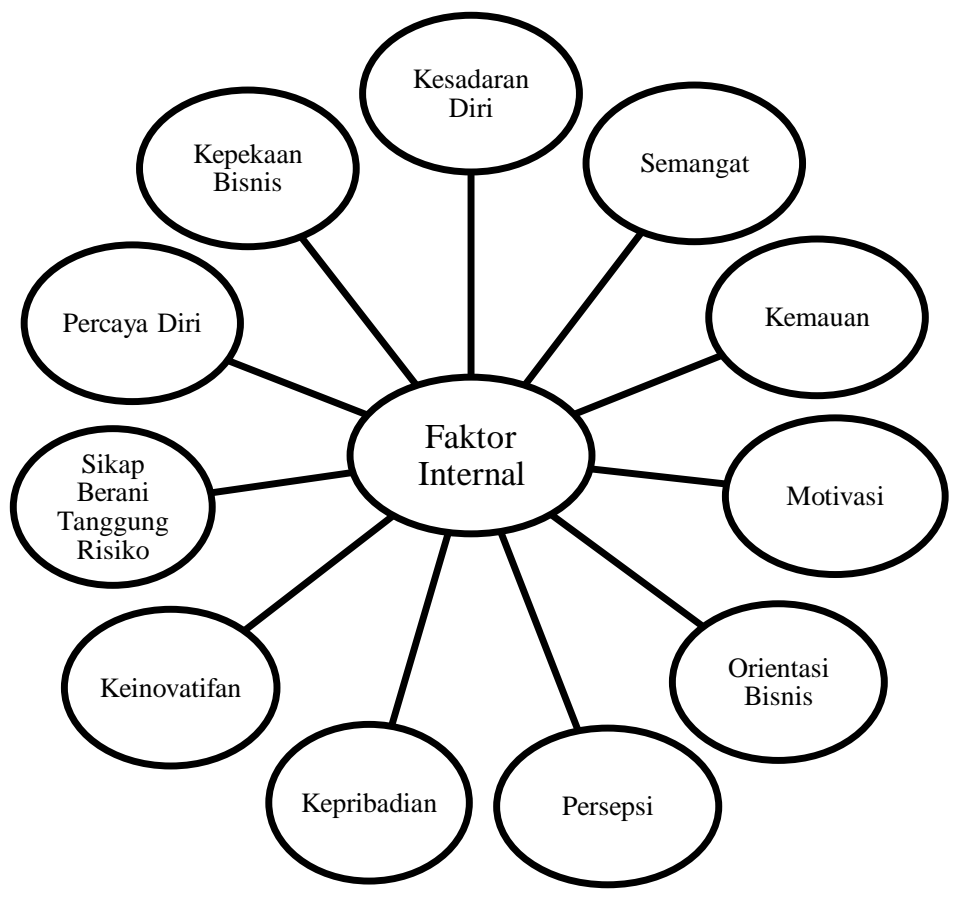

Gambar 1. Ragam Faktor Internal Penentu Kewirausahaan Petani

Deretan faktor internal penentu bagi kewirausahaan petani yang tertera pada Gambar 1 perlu dikelola secara profesional melalui proses sosialisasi berkelanjutan yang menggunakan metode pendidikan tak formal partisipatif. Hal ini menjadi terasa penting ketika disadari pengembangan jiwa dan kemampuan kewirausahaan turut ditentukan oleh latar belakang pendidikan, lingkungan keluarga dan pengalaman kerja seseorang (Hisrich and Peter, 1992).

Faktor internal berikutnya yang ikut menentukan ialah ketertarikan, minat dan etos kerja. Beberapa faktor tersebut sesuai dengan pemikiran Siagian (1999) yang menjelaskan bahwa kewirausahaan ialah suatu kesatuan terpadu dari semangat, nilai, prinsip, sikap, kiat, seni dan tindakan nyata yang sangat perlu, tepat juga unggul dalam memberikan pelayanan kepada berbagai pihak. Disamping ragam faktor internal penentu, terdapat juga 
beberapa faktor eksternal yang berpotensi sebagai pendukung dan penghambat. Pada Gambar 2 terlihat beberapa faktor eksternal penentu kewirausahaan petani dalam mengelola bisnis kreatif di pedesaan.

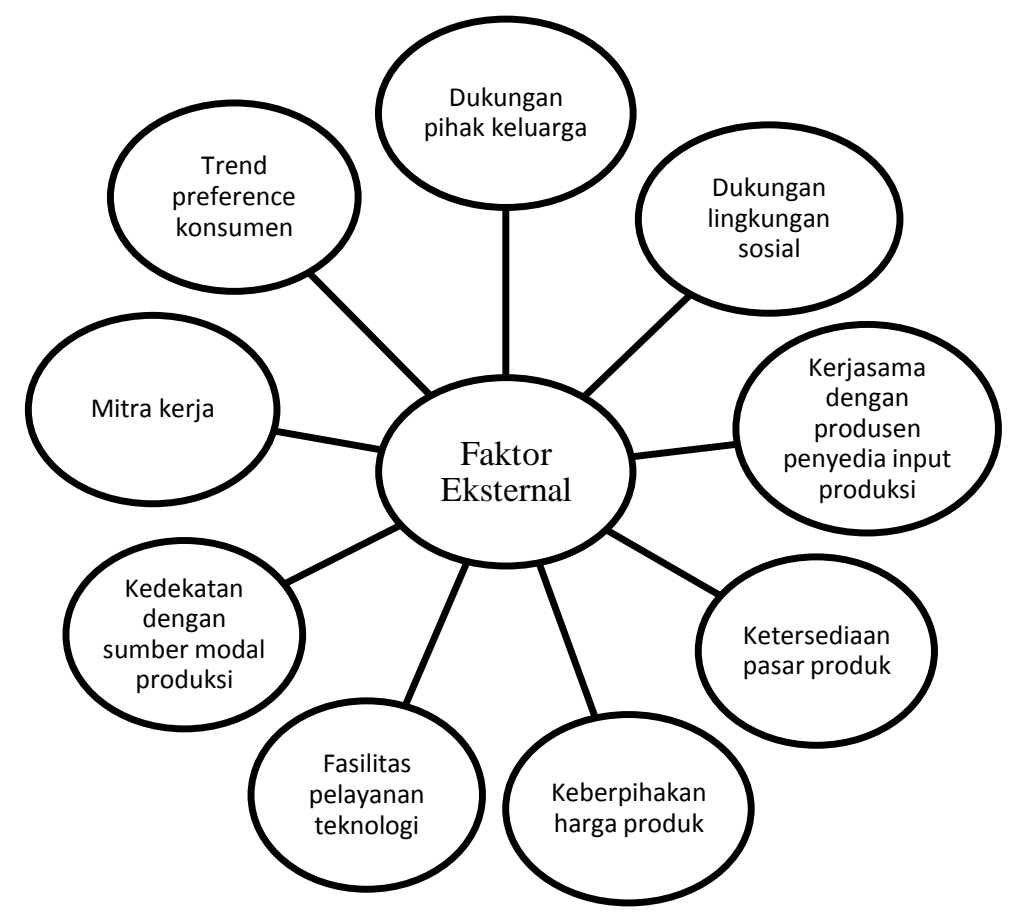

Gambar 2. Ragam Faktor Eksternal Penentu Kewirausahaan Petani

Daya keberpengaruhan setiap faktor eksternal penentu tergantung pada jalinan interaksi, hubungan sosial, komunikasi antara petani dengan berbagai pihak terkait. Beberapa keadaan lain yang berpotensi mewarnai kekuatan pengaruh faktor eksternal penentu ialah ketersediaan fasilitas pelayanan informasi teknologi inovatif, modal produksi, harga dan pasar yang tersedia di lingkungan desa. Optimalisasari pengaruh faktor eksternal penentu yang mendukung pengembangan kewirausahaan petani dalam pengelolaan bisnis mikro yang produktif dan kreatif lebih mudah terlaksana melalui penguatan kerjasama dan kemitraan berpola mutualisme dengan pendekatan kelompok.

\section{FUNGSI KEWIRAUSAHAAN PETANI BAGI PENGELOLAAN BISNIS MIKRO}

Sebelum membahas lebih lanjut mengenai fungsi kewirausahaan bagi pengelolaan bisnis mikro maka terlebih dahulu perlu mengenali beberapa ciri petani yang telah termasuk kategori wirausaha. Mengacu pada pemikiran Schumpeter (1961) maka seseorang yang dapat disebut sebagai wirausaha mempunyai beberapa ciri yakni: pertama, mampu mengidentifikasi pencapaian sasaran dan tujuan serta mempunyai kepekaan bisnis. Ciri yang kedua dimiliki seorang wirausaha adalah mampu menanggung risiko keuangan dan waktu atas segala keputusan serta tindakan perilaku untuk kepentingan pengelolaan usaha bisnis.

Ciri ketiga mampu melakukan tahapan kegiatan perencanaan, pengorganisasian dan pelaksanaan. Adapun ciri keempat yakni mampu bekerja keras untuk mencapai keberhasilan usaha dan ciri kelima mampu menjaga hubungan baik dengan pelanggan, pedagang, sumber dana dan pihak lainnya. Seorang wirausaha juga perlu memiliki kemampuan melaksanakan evaluasi kelayakan usaha bisnis mikro yang dikelola termasuk analisis untung rugi. Lebih spesifik, Lambing and Kuehl (2006) menguraikan beberapa ciri seorang wirausaha seperti yang terlihat pada Gambar 3. 


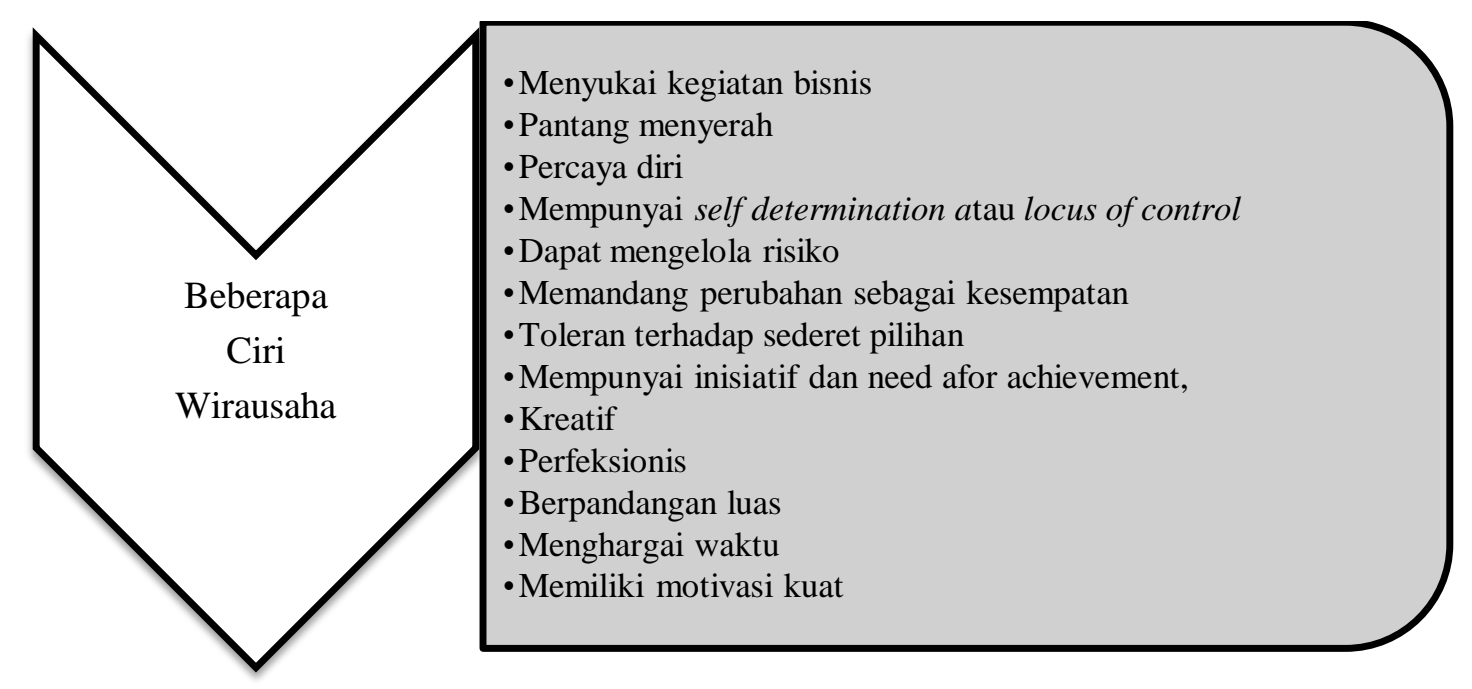

Gambar 3. Beberapa Ciri Wirausaha (Lambing, et all., 2000)

Berdasarkan uraian berbagai ciri wirausaha yang telah dijelaskan maka dapat dinyatakan petani yang telah mempunyai jiwa dan semangat kewirausahaan tentu mempunyai kemampuan dalam memanfaatkan berbagai potensi sumberdaya yang tersedia dalam setiap kesempatan dan peluang untuk mengelola bisnis mikro yang berorientasi pada pencapaian keuntungan dan kemanfaatan ekonomis lain. Setelah memahami beberapa ciri yang melekat pada figur seorang wirausaha maka diketahui bahwa kewirausahaan mempunyai beberapa fungsi penting yang mendukung petani efisien mengembangkan bisnis mikro di pedesaan. Beberapa fungsi kewirausahaan petani bagi pengelolaan bisnis mikro mencakup: meningkatkan melek usaha produktif dan kreatif, mengembangkan naluri dan kepekaan bisnis, meningkatkan keberanian menanggung risiko, memperluas kesempatan meraih keuntungan dan surplus usaha, memperkuat posisi tawar, meningkatkan produktivitas dan kreativitas serta menguatkan daya saing.

Pelaksanaan fungsi kewirausahan petani sewaktu-waktu bisa mengalami hambatan akibat berbagai tekanan, yang bersumber dari kendala ekonomi, sosial, budaya dan lingkungan. Hasil penelitian Dumasari dan Sulistyani (2002) membuktikan bahwa fungsi kewirausahaan petani mandeg ketika dihadapkan pada beberapa kondisi yang merintangi keberlanjutan usahatani tanaman pangan. Beberapa faktor penyebab terjadinya kemandegan fungsi kewirausahaan petani tersebut beserta tingkat pengaruhnya terurai pada Gambar 4. 


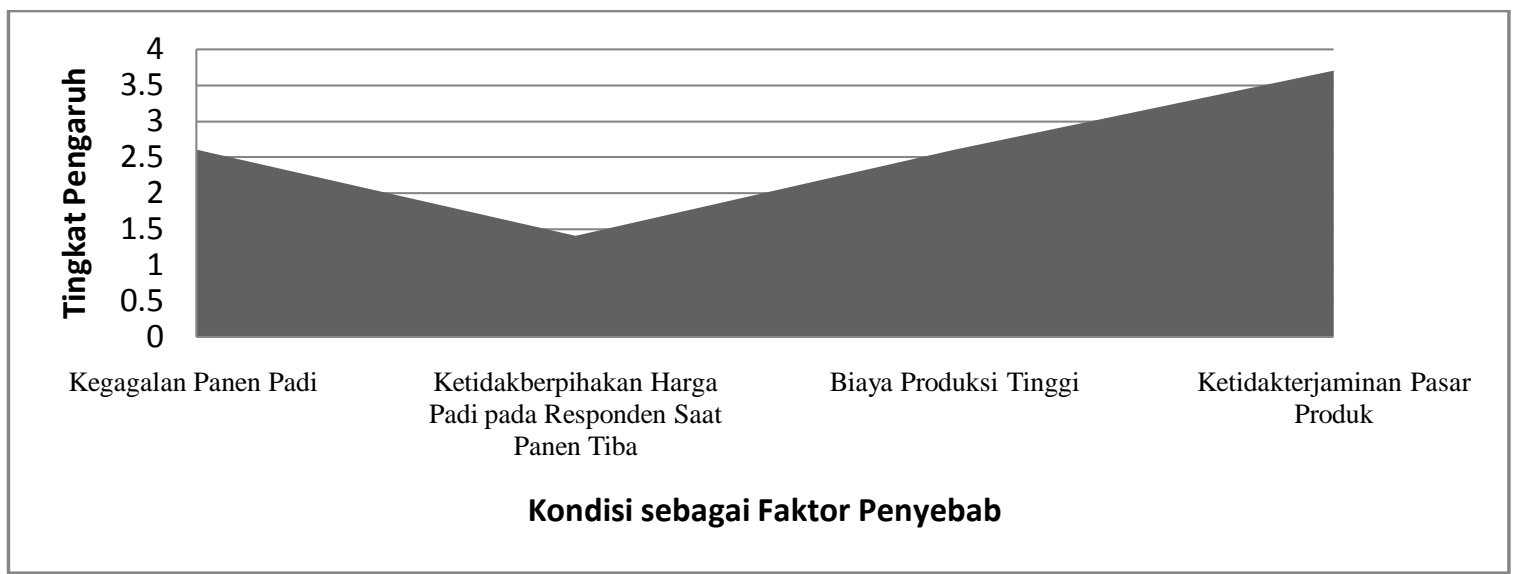

Gambar 4. Beberapa Faktor Penyebab Kemandegan Fungsi Kewirausahaan Petani Tanaman Pangan (Diolah dari Hasil Penelitian Dumasari dan Sulistyani (2002)

\begin{abstract}
Fungsi strategis lain yang penting diperhatikan adalah meningkatkan kemandirian ekonomi, menambah katup pengaman nafkah produktif sebagai alternatif sumber perolehan pendapatan, mengembangkan rasionalitas, menghindari persoalan kerugian dan kebangkrutan serta memberi nilai tambah pada produk yang dihasilkan dari bisnis mikro. Selain itu, masih ada fungsi strategis selanjutnya yakni yang berkenaan dengan peningkatan kelayakan ekonomi bisnis mikro dan mempermudah akses dan keterjangkauan informasi harga serta pasar.
\end{abstract}

\section{KESIMPULAN DAN SARAN}

Kewirausahaan petani merupakan salah satu kebutuhan strategis dalam pengelolaan berbagai jenis bisnis mikro di pedesaan. Beberapa faktor penentu memberi pengaruh terhadap pengembangan kewirausahaan petani. Ragam faktor penentu tersebut sebagian bersifat internal dan lainnya eksternal. Kemampuan dalam mempengaruhi kewirausahaan petani dari setiap faktor penentu berbeda. Pada kondisi dan waktu tertentu menjadi faktor pendukung sementara pada kondisi dan waktu lain justru sebagai penghambat. Kewirausahaan petani ternyata mempunyai beberapa fungsi strategis bagi pengelolaan bisnis mikro di pedesaan.

Upaya pemberdayaan petani melalui pengelolaan beragam jenis bisnis mikro membutuhkan pengembangan kewirausahaan yang berbasis sumberdaya lokal. Pengembangan kewirausahaan tersebut potensial dilakukan melalui kegiatan pendidikan tak formal dengan mengandalkan pendekatan kelompok secara partisipatif.

\section{DAFTAR PUSTAKA}

Dumasari dan Sulistyani Budiningsih. 2002. Pengembangan Kewirausahaan pada Petani Pembudidaya Padi Sawah di Pedesaan. Laporan Hasil Penelitian Skim Dosen Muda. DP2M DIKTI. Universitas Muhammadiyah Purwokerto. Purwokerto.

Dumasari, Watemin dan Sumadi Sudrijat. 2007. Model Pemberdayaan Wanita Tani Miskin melalui Pengembangan Teknologi Modifikasi Produk Limbah Industri Pertanian menjadi Tourism Souvenir Goods Khas Pariwisata Banyumas. Laporan Hasil Penelitian Skim Hibah Bersaing Tahap I. DP2M DIKTI. Universitas Muhammadiyah Purwokerto. Purwokerto.

Dumasari dan Watemin. 20I0. Pemberdayaan Petani Miskin melalui Pengembangan Usaha Mikro Tourism Souvenir Goods dari Limbah Pertanian dengan Pemanfaatan Teknologi Modifikasi Produk Ramah Lingkungan (Tahap I). Laporan Hasil Penelitian Skim Hibah Bersaing Tahap I. DP2M DIKTI. Universitas Muhammadiyah Purwokerto. Purwokerto. 
Dumasari, Tri Septon Muji Rahayu dan Sulistyani Budiningsih. 2013. Pengembangan Usaha Mikro Souvenir Kreatif Olahan Limbah Kelapa dengan Teknologi Modifikasi Desain Produk sesuai Trend Pasar untuk pemberdayaan Petani Miskin. Laporan Hasil Penelitian Hibah Unggulan Perguruan Tinggi. DITLITABMAS DIKTI. Universitas Muhammadiyah Purwokerto. Purwokerto.

Bayu, Kartib dan Eri Mustari. 2012. Pengaruh Sikap Kewirausahaan dan Kompetensi Petani terhadap Penerapan Teknologi Padi Organik beserta Implikasinya pada Pemanfaatan Potensi Lokal (Studi Kasus Petani P3A Mitra Cai Mekarsari, Kecamatang Jatitujuah, Majalengka, Jawa Barat. Artikel Dimuat pada Prosiding Seminar Nasional Improving Performance for Improving Environment. Fakultas Ekonomi. Universitas Negeri Semarang. Semarang.

Hisrich, R. D., and M. P., Peters. 1992. Entrepreneurship: Starting Developing and Managing a New Enterprise. 2nd Edition. Homewood: B.P.I/Irwin. USA.

Lambing, Peggy A., and Charles R., Kuehl. 2006. Entrepreneurship. 4th Edition. Prentice Hall. Inc New Jersey. USA.

Meredith. Geoffrey Grant. Robert E., Nelson and Philip A., Neck. 2005. The Practice of Entrepreneurship. International Labour Office. Genewa.

Pujiati, Utami dan Dumasari. 2012. Pengembangan Bisnis Kreatif Aneka Produk Singkong dengan Variasi Cita Rasa sesuai Ekspektasi Selera Konsumen untuk Diversifikasi Nafkah Petani di Pedesaan. Laporan Hasil Penelitian Hibah Unggulan Perguruan Tinggi. DITLITABMAS DIKTI. Universitas Muhammadiyah Purwokerto. Purwokerto.

Ratnawati, Susi. 201 I. Pemberdayaan Perempuan Miskin di Pedesaan melalui Pengembangan Kewirausahaan. Artikel Dimuat pada Jurnal Kewirausahaan Volume 5 Nomor 2 Desember 2011. Lembaga Penelitian dan Pengabdian
Masyarakat. Universitas Widya Kartika Surabaya. Surabaya.

Ropke. J., 2004. On Creating Entrepreneurial Energy in the Ekonomi Rakyat Case Indonesian Cooperatives. Artikel Dimuat dalam Jurnal Ekonomi Kewirausahaan. Volume III Nomor 2 Juli 2004. Bandung.

Schumpeter, Joseph Alois. 196I. The Theory of Economic Development: an Inquiry into Profits, Capital, Credit, Interest and the Business Cycle. Oxford University Press. New York.

Siagian, Salim. 1999, Peranan Kewirausahaan Pengembangan Koperasi, Jurnal Usahawan No. 07 TH XXVIII Juli 1999. Lembaga Manajemen. Fakultas Ekonomi. Universitas Indonesia. Jakarta.

Identitas Penulis

Nama Lengkap: Ir. Dumasari, M.Si

Alamat:

Perumahan Tegal Sari Indah

JI. Kenanga XVI Blok N 9-10 Purwokerto.

Nomor Telepon/Faks: (0281) 6843375/

(0281) 6843375

Instansi:

Faktltas Pertanian.

Universitas Muhammadiyah Purwokerto.

Alamat Instansi: Kampus UMP Jalan Raya

Dukuh Waluh Purwokerto

Alamat Email/HP:

dumasarilumongga@yahoo.com

085747852243 